\title{
Re-energizing the G20 to Thwart a Global Systemic Crisis
}

\author{
Guangyao Zhu
}

\begin{abstract}
Maintainingpolitical order and governance on a global level should be centered on theUnited Nations, follow the principles in the UN charter and be supported by the IMF, World Bank and WTO. The role of China could potentially be key in global recovery as mankind conquers COVID-19. China's ability to keep the virus under control, restart its economy and maintain growth, while, as of early 2021, much of the rest of the world continued to flounder, positions China as a driver for future economic development and trade growth. The importance of multilateral governance systems in the resolution of COVID-19 cannot be overstated. This is especially true of the G20 system. The G20 has the ability to mobilize the resources of the most influential and powerful countries in the world. G20 members, potentially in concert with China, have the power to put the world back on a path of multilateralism that emphasizes cooperation and consensus. COVID-19 transcends borders, nationalities and political systems. All nations must put aside pride and biases and replace them with more mutual respect, exchange suspicion for understanding and accusations with action. If nations are united, mankind can overcome the COVID19 pandemic and work toward the continued development of economies and better manage the global community.
\end{abstract}

Keywords UN centered political order and governance - The role of China could potentially be key in global recovery from COVID-19 - The importance of multilateral governance systems in the resolution of COVID-19 cannot be overstated - The G20 has the ability to mobilize the resources of the most influential and powerful countries in the world - COVID-19 is a borderless threat • If nations are united, mankind can overcome the COVID-19 pandemic

The COVID-19 pandemic that is currently sweeping the world is a systemic crisis of global proportions on a scale that hasn't been seen since World War II. It is also the biggest global public health crisis since the $1918 \mathrm{flu},{ }^{1}$ which infected over 500 million and claimed the lives of over 50 million people around the world.

\footnotetext{
G. Zhu ( $\varangle)$

Counsellor's Office of the State Council, Beijing, China

${ }^{1}$ www.cdc.gov/flu/pandemic-resources/1918-pandemic-h1n1.html.

(C) The Author(s) 2021

H. Wang and A. Michie (eds.), Consensus or Conflict?, China and Globalization, https://doi.org/10.1007/978-981-16-5391-9_10
} 
COVID-19 has also spawned the biggest economic crisis since the 2008 financial crisis as well as a crisis in global governance that has impeded world peace and global development. However, there is little doubt that humanity will overcome this pandemic and that the current era of peaceful global development will not come to an end because of COVID-19.

The most important response to a pandemic like COVID-19 is for the world to communicate and work together to overcome the massive uncertainties that come with such a crisis. Specific actions required to tackle these uncertainties fall in four main areas-first, tracking the course of the pandemic; second, forecasting its impact on the global economy; third, ensuring the stability of industry and supply chains and fourth, assessing the impact of the pandemic on systems of global governance.

As of April 2021, this global pandemic has affected the health of over 130 million people and taken nearly three million lives. As a common enemy of all of humanity, the rise and fall in the number of cases, the emergence of new variants and the unequal distribution of vaccines throughout the world only add to the uncertainties about what the future will bring.

\section{The Financial Impact of COVID-19}

COVID-19 continues to impact the global economy, and the economic crisis that we face will last for years. The IMF estimates that global growth contracted at $3.5 \%$ in 2020. This is much worse than the $0.1 \%$ negative growth that the world saw in 2009 after Lehman Brothers went bankrupt on September 15, 2008, which led to the 2008 global financial crisis. In early 2021, and 12 months after COVID-19 was identified, the impact that this pandemic will have on the global economy has only begun to manifest itself.

The United Nations estimates that global direct investment dropped by $30-40 \%$ in 2020 , higher than the $35 \%$ drop that was seen in 2009 after the global financial crisis. The WTO estimates that global trade dropped somewhere between 13 and $32 \%$ in 2020, which is also much higher than the drop that was seen in 2009 following the financial crisis. If we compare this with 1933, when global trade fell $30 \%$ due to the Great Depression, we can see just how big a challenge this presents for the world economy. Some say that the impact of the COVID-19 pandemic has affected only supply and demand. These comments suggest COVID-19 hasn't dramatically influenced the financial sector. However, in the coming years, we need to be prepared for rapid falls in the price of assets, a drastic increase in defaults on loans and the potential of bankruptcy of financial institutions.

Newly emerging markets should also be watched. The liquidation of USD 100 billion over the course of three months, by various countries, was four times the amount that bled from newly emerging markets during the 2008 global financial crisis. Argentina was one of the earliest countries to submit loan restructuring requests to the IMF and private lenders. This indicates that both developed countries and emerging economies have both felt the financial pressure caused by the COVID-19 
pandemic. In March 2020, the G20 leaders reached an agreement to commit USD 50 billion to the fight against COVID-19. This amount was based on recommendations from international economic organizations, but only a month later the situation became increasingly worse and by May 2020 the United States alone had allotted USD 90 billion in financial support.

By the end of 2020, the US Federal Reserve amassed fiscal debt of USD 90 billion, while also providing USD 40 billion in the form of loans to support American businesses. Desperate times call for desperate measures and coordination between fiscal and monetary policies is critical. At the time, the Federal Reserve provided financial support to small and medium businesses without collateral, but it demanded that the Treasury Department provide guarantees for the loans. Clearly, this unique challenge has required innovative macroeconomic ideas that can only be achieved through cooperation and coordination.

Today's supply and industry chains are the result of many years of work by multinational companies that have followed trends in economic globalization, characterized by relative advantage, division of labor across borders and goals of efficiency and profit. They also reflect the nature of resources, labor and market conditions in different countries as well as the return on investment and operating environment in various countries.

\section{Challenges Facing Industries and Systems}

The pressure of the COVID-19 pandemic has caused some people to question existing industry and supply chains, expressing a desire to "bring home" certain industries, but this is not something that can be accomplished overnight. We must listen to business people in various countries and the opinions of multinational companies in particular. We should also be aware that these industry and supply chains may also need to be adjusted in the wake of COVID-19. These are a few of the main areas in which I believe they should be adjusted:

The first is in terms of security. Multinationals will naturally emphasize the concentration of industry chains and make both supply and industry chains as simple as possible, because they wish to make them as secure as possible, especially in unusual circumstances.

The second is the impact of certain policies on industry and supply chains. This includes bringing back the pharmaceutical industry to the United States, which has led to similar calls for the return of a wider range of manufacturing sectors. This has been discussed for a number of years, but in the context of the pandemic, pharmaceuticals have been a special focus. However, what can be done is ultimately limited because of the allocation of resources and issues of market demand, which includes the supply of raw materials and cannot be accomplished overnight.

The third is a more rapid restructuring of regional industry and supply lines in the context of COVID-19. Whether it is geographic proximity or similarities in systems, 
regulations and standards, or even better integration, new changes will likely come to regional industry and supply chains.

The fourth element is the impact of the digital economy on industry and supply chains. This was first seen in the digitalization of industries, in which I believe China has a unique advantage. This gain comes from extremely convenient infrastructural supports that ensure massive logistical capabilities as well as the world's most extensive mobile telephony base station coverage, which enables huge volumes of data to be exchanged. China also leads in the use of convenient forms of payment and electronic payment systems. With all of these digital advantages, it is likely that China will be one of the most efficient places in the world in terms of the digitalization of industry and supply chains.

Ultimately, stable industry and supply chains are in the interest of all countries and we should strengthen communication and coordination on policies to ensure that they remain stable.

\section{China's Role in Recovery After COVID-19}

The world is changing, and China, currently the world's largest developing country and the second-largest economy, has turned its sights to taking care of business at home. President Xi Jinping has placed the physical and economic recovery of the country's 1.4 billion people at the top of his list of priorities. This means that China is in a position to potentially help much of the world, especially the developing world, to recover more quickly from the devastating effects of the pandemic. Similar to the United States after World War II, China could potentially work to help countries recover economically, reform systems of global governance and ensure that globalization trends in a direction that is beneficial for all countries.

The International Monetary Fund (IMF) predicts that data will confirm that China will be the only major economy to maintain positive growth in 2020 , growing at a rate of $1.9 \%$ overall (Q1 6.8\%, Q2 3.2\%, Q3 4.9\%, Q4 6\%). The IMF's forecast for China's economic growth is $8.2 \%$ for 2021 . While this will enable China to maintain confidence and optimism on economic growth, it must also be very prudent and ensure that development is both healthy and sustainable, which is one of the goals of its current "dual circulation" policy that will balance domestic and international production and trade.

One specific way in which China is maintaining this trend of growth is the start of a large number of new infrastructure projects, which is a key element in the "six priorities" 2 as laid out by the central government. To accomplish this, the central government has arranged for a fiscal deficit of 3.6\%, an increase of RMB 1 trillion, as well as RMB 1 trillion in special treasury bonds and RMB 3.75 trillion in local special treasury bonds for a total of nearly RMB 8 trillion. RMB 2 trillion of this is

${ }^{2} 1$. Job security; 2 . basic living needs; 3 . operations of market entities; 4 . food and energy security; 5. stable industrial and supply chains; and 6. normal functioning of primary-level governments. 
allocated exclusively for local governments to support employment, market players and basic livelihood with a special focus on the welfare of small and medium-sized enterprises, which is seen as key to China's economic resilience and vitality.

In early 2021, the "14th Five-Year Plan" and the "Long-Range Objectives Through the Year 2035" were adopted at the fifth plenary session of the 19th CPC Central Committee and by all accounts mark a new trend in development objectives that will no doubt affect how China interacts with the world. The overall size of China's economy is already something that can't be ignored, but the purchasing power of its people is also something that should be watched more closely. China's gross national product (GNP) was USD 14.3 trillion in 2019, while per capita GNP reached USD 10,261. According to the latest adjusted data from the World Bank, China is not far from the threshold for high-income countries, which is currently set at USD 12,535 per capita of GNP.

As the world's two largest economies, China and the United States should adhere to the principles of non-conflict, non-confrontation, mutual respect, cooperation and win-win, which are in the interests of both their peoples and peaceful global development. Objective economic development has resulted in a narrowing of the gap between the Chinese and US economies, but we must remain acutely aware that the GDP per capita in 2019 in the United States was USD 66,000, over six times that of China. This clear difference points out that while China is in a position as a country to impact and even possibly guide the world, it cannot ignore the overwhelming economic heft of the United States. This is why it has always been China's position that each country should make its own contribution in the process of building a community that focuses on shared prosperity for mankind.

\section{Three Points for Moving Forward}

To overcome the current crisis, there must be a systematic, holistic, strategic thinking that enables the countries of the world, especially key players, to return to a spirit of unity and collaboration. Unfortunately, the United States, as the world's largest economy and the largest developed country, inflicted severe damage to the global governance system by withdrawing from the multilateral institutions and agreements in 2020. It is essential that the United States return to multilateralism and a path of peaceful global development, which is ultimately in line with the interests of the United States.

There is an urgency and importance to restoring and strengthening the functions of the G20. The global public health crisis, the global economic recession and the issues in global governance triggered by the COVID-19 pandemic compounded existing problems, which created a serious systemic crisis that humanity has not seen since World War II. However, the international community failed to work together to effectively respond as it did when it responded to the global financial crisis in 2008. As of the early months of 2021, and a full year into the COVID-19 pandemic, the G20 was still basically at a standstill. 
"Conflict reduction" under the leadership of the G20 can only be regarded as a part of the overall function of the G20. Its most important function is actually to foster cohesion and solidarity and cooperation of major countries in times of crisis, focusing on coordinating macroeconomic policies and other policy issues. The G20 should take immediate action and coordinate policy to achieve the following three goals.

First, we need to coordinate macroeconomic policies, including both fiscal policy and monetary policy. By early 2021, countries around the world had already invested USD 15 trillion to ensure economic stability, support employment and efforts to counter economic depression. However, the results have not been encouraging. In terms of monetary policy, major economies have implemented negative interest rate policies. The European Central Bank currently has an interest rate of $-0.5 \%$, and the Bank of Japan has an interest rate of $-0.1 \%$. The US Federal Reserve (The Fed) has kept interest rates at zero since March and despite the 10-year dollar bond yield being set at $0.7 \%$, after taking inflation into account, the rate is actually negative. The Fed also stated that it will not normalize interest rates (i.e. change its zero interest rate policy), until 2023. International coordination is urgently needed in this regard.

Second, the G20 needs to reach a policy consensus on digital taxation and digital currency, effective supervision of digital platforms and prevention of a "New Cold War" as soon as possible. Progress had already been made in terms of digital taxation prior to the pandemic, with the G20 reaching a consensus and taking actual steps, but momentum has been lost and there is an urgent need to restore the functions of the $\mathrm{G} 20$ in this area.

Third is trade policy. The WTO is now at a standstill, mainly due to the actions of the United States, which even went so far as to challenge the 2020 election of the WTO Director-General. In order to ensure the survival of the WTO, the G20 member states urgently need to rally to form an effective policy consensus. Some in the United States have called for decoupling, which would be unlikely and incredibly difficult, but at the same time not too long ago, the US representative had asked to establish a mechanism by which China could join the G20 under the format of the China-US Strategic Economic Dialogue.

This tells us that while things have stagnated, there is still room for discussion and functionality to return to the G20. This is why maintaining close coordination between China and the United States is not only in the interest of China and the United States but also in the interest of the world. In the field of global cooperation, it is time to return to the multilateral framework and strengthen the role of the G20.

\section{Conclusion}

Ideally, maintaining political order and governance on a global level should be something ensured through the United Nations, following the principles in its charter with support from the IMF, World Bank and WTO. As a specialized arm of the UN, the WHO should shoulder the responsibility of setting health policies and monitoring 
their execution. This is a massive burden as the COVID-19 pandemic continues to ravage the world, made even more difficult by the Trump administration and its lack of interaction and threat to leave the WHO entirely, which severely damaged its ability to tackle this challenge.

The role of China could potentially be key in global recovery as we come out of the worst of the COVID-19 pandemic. China's ability to keep the virus under control, restart its economy and maintain growth, while much of the rest of the world continued to flounder, positions China as a driver for future economic development and trade growth. This economic stability, underpinned in 2021 by the launching of its most recent five-year plan and other development goals, as well as rising income levels, makes China a key part of any plan for global economic recovery.

The importance of multilateral governance systems in the resolution of the negative impact of COVID-19 cannot be overstated. This is especially true of the G20, which has the ability to mobilize the resources of the most influential and powerful countries in the world, coordinating them to effectively resolve the core challenges that the world faces. In a post-Trump world, the G20 member countries, potentially in concert with China, have the power to put the world back on a path of multilateralism that emphasizes cooperation, coordination and consensus, which is essential.

The fight against COVID-19 is something that transcends borders, nationalities and political systems. What's more, there is no aspect of life that it has not affected. It has impacted our health, our economies and our futures. We must unite against this common challenge and cooperate to overcome it. I recommend that we put aside our pride and biases and replace them with more mutual respect, exchange suspicion for understanding and accusations with action. If we are united, we can overcome the COVID-19 pandemic. We can, and must, work toward the continued development of our economies and better manage our global community.

Guangyao Zhu is a former Vice Minister of Finance of China (2010-2018). He previously worked in the World Bank as a Senior Advisor, Alternate Executive Director and Executive Director for China. He currently serves as a Counsellor of the State Council of China. He graduated from Finance Science Research Institute of the Finance Ministry of the PRC with a Masters Degree in Economics. He has rich experience in dealing with international economic and financial affairs. With his deep knowledge of the development of the International Financial Reporting Standards (IFRS) and the international convergence of Chinese accounting standards, he also plays a vital role in promoting the research in accounting theory in China. 
Open Access This chapter is licensed under the terms of the Creative Commons AttributionNonCommercial-NoDerivatives 4.0 International License (http://creativecommons.org/licenses/bync-nd/4.0/), which permits any noncommercial use, sharing, distribution and reproduction in any medium or format, as long as you give appropriate credit to the original author(s) and the source, provide a link to the Creative Commons license and indicate if you modified the licensed material. You do not have permission under this license to share adapted material derived from this chapter or parts of it.

The images or other third party material in this chapter are included in the chapter's Creative Commons license, unless indicated otherwise in a credit line to the material. If material is not included in the chapter's Creative Commons license and your intended use is not permitted by statutory regulation or exceeds the permitted use, you will need to obtain permission directly from the copyright holder.

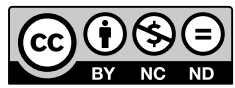

